\title{
UPAYA PENINGKATAN KESEHATAN MASYARAKAT MELALUI WEBINAR "SEHAT DAN BUGAR MENYAMBUT IDUL FITRI DI TENGAH PANDEMI COVID-19"
}

\author{
Linda Riski Sefrina ${ }^{1}$, Habibi Hadi Wijaya ${ }^{2}$, Nazhif Gifari ${ }^{3}$ \\ ${ }^{1}$ Prodi Gizi UNSIKA, ${ }^{2}$ Prodi IKOR UNSIKA, ${ }^{3}$ Prodi Gizi UEU \\ Email: lindariski@gmail.com
}

\section{A. PENDAhULUAN}

Hari Raya Idul Fitri merupakan hari raya keagaman yang dilaksanakan sebagian besar masyarakat di Indonesia yang notabene merupakan muslim. Hari Raya Idul Fitri atau Lebaran di Indonesia adalah hari raya umat Islam yang jatuh pada tanggal 1 Syawal pada penanggalan Hijriah. Pada hari Raya ini sebagian besar masyarakat Indonesia berkumpul dengan keluarga dan makan ersama. Hidangan yang khas dari hari raya Idul Fitri berbedabeda di setiap daerah atau suku di Indonesia, akan tetapi yang paling sering dijumpai adalah ketupat dan opor ayam. Selain hidangan tersebut, biasanya juga ada hidangan seperti kue kering maupun jajanan pasar. Hal tersebut dapat mempengaruhi peningkatan jumlah asupan energi.

Berdasarkan

penelitian

sebelumnya, pada saat bulan puasa, terdapat kecenderungan mengkonsumsi makanan tinggi lemak dan dan tinggi protein meskipun frekuensi makan dan jumlah asupan makanan menurun (Gharbi et al, 2003). Kebiasaan makan ini akan dipertahankan sampai sesudah Idul fitri (Al-Hourani, 2007). Kebiasaan ini apabila diterapkan dapat meningkatkan IMT (Indeks Massa Tubuh), sehingga masyarakat berpotensi menderita overweight atau obese. Overweight maupun obesitas merupakan faktor resiko penyakit degeneratif sehingga ini perlu untuk dicegah (Ilona et.al, 2017). Salah satu cara yang dapat digunakan untuk mencegah peningkatan IMT adalah dengan menerapkan olahraga atau aktifitas fisik. WHO telah menyarankan bahwa untuk dapat mencegah penyakit tidak menular, masyarakat dapat melakukan aktivitas fisik minimal 150 menit/minggu.

Promosi kesehatan bertujuan untuk membantu masyarakat menjadikan gaya hidup mereka sehat. Salah satu bentuk dari promosi kesehatan ini adalah melalui kegiatan seminar. Pandemi Covid-19 telah membuat perubahan yang biasa dikenal dengan Adaptasi Kebiasaan Baru (AKB). Promosi Kesehatan dalam kondisi New Normal yang dapat dilakukan adalah seminar online atau webinar. Kegiatan ini dapat mencapai tujuan kegiatan, dengan sasaran yang lebih luas, dan minim penularan Covid19. Oleh karena itu, penting untuk tetap melakukan promosi kesehatan di saat pandemi covid-19.

\section{B. TUJUAN KEGIATAN}

Tujuan pengabdian masyarakat ini adalah meningkatkan pengetahuan masyarakat terutama tentang pentingnya sehat dan bugar saat Pandemi Covid-19 dan cara mendapatkan tubuh yang sehat dan mencegah penambahan berat badan pada saat hari raya Idul Fitri $1441 \mathrm{H}$.

\section{BENTUK KEGIATAN}

Metode pendekatan yang dilakukan yaitu melalui kegiatan promosi Kesehatan dalam bentu Web Seminar atau Webinar. Bentuk kegiatan ini dilakukan untuk mencegah penyebaran Pandemi Covid-19. 
Webinar ini diselenggarakan melalui Google Meet.

\section{SASARAN}

Sasaran dalam pengabdian ini adalah masyarakat di seluruh Indonesia. Kegiatan ini telah diikuti oleh sebnayak 188 peserta dari berbagai provinsi di Indonesia seperti dalam table berikut ini:

\begin{tabular}{|c|l|c|c|}
\hline No. & Provinsi asal peserta & Jumlah & $\%$ \\
\hline 1 & Jawa Barat & 88 & $47 \%$ \\
\hline 2 & DKI Jakarta & 26 & $14 \%$ \\
\hline 3 & Jawa Tengah & 15 & $8 \%$ \\
\hline 4 & Jawa Timur & 35 & $19 \%$ \\
\hline 5 & Sumatera Utara & 1 & $1 \%$ \\
\hline 6 & Sumatera Barat & 1 & $1 \%$ \\
\hline 7 & Sumatera Selatan & 2 & $1 \%$ \\
\hline 8 & Bengkulu & 17 & $9 \%$ \\
\hline 9 & Batam & 1 & $1 \%$ \\
\hline 10 & Kalimantan Timur & 1 & $1 \%$ \\
\hline 11 & Sulawesi Selatan & 1 & $1 \%$ \\
\hline & Total & 188 & $100 \%$ \\
\hline
\end{tabular}

\section{E. SUSUNAN ACARA}

Acara webinar diselenggarakan tanggal 21 Mei 2020 pukul 13.00-15.30WIB dengan susunan acara sebagai berikut :

\begin{tabular}{|c|c|c|}
\hline Waktu & Kegiatan & Keterangan \\
\hline $13.00-13.05$ & Pembukaan & Pembukaan seminar oleh host \\
\hline $13.05-13.10$ & Laporan \& pembukaan & $\begin{array}{lllll}\begin{array}{l}\text { Laporan ketua pelaksana } \\
\text { pembukaan acara }\end{array} & & \text { webinar } 2020 \text { dan } \\
\end{array}$ \\
\hline $13.10-14.00$ & Penyampaian pemateri 1 & $\begin{array}{l}\text { Pembukaan oleh moderator dan pembacaan } \mathrm{CV} \\
\text { pemateri } 1 \& 2 \text {, pemaparan materi dari pemateri I }\end{array}$ \\
\hline $14.00-14.45$ & Penyampaian pemateri 2 & Pemaparan materi dari pemateri II \\
\hline $14.45-15.05$ & $\begin{array}{l}\text { Sesi tanya jawab ( } 2 \text { sesi, } 1 \text { sesi } \\
\text { terdapat } 3 \text { pertanyaan) }\end{array}$ & \\
\hline $15.05-15.20$ & Penyampaian kesimpulan & $\begin{array}{l}\text { Penyampaian kesimpulan materi oleh moderator. } \\
\text { Moderator memberikan alih seminar kepada host. }\end{array}$ \\
\hline $15.20-15.25$ & Foto Bersama & $\begin{array}{l}\text { Semua pelaksana Webinar menyalahkan kamera. Dan } \\
\text { yang akan melakukan screen capture adalah Acara. }\end{array}$ \\
\hline $15.25-15.30$ & Penutupan & Penyampaian penutup oleh host \\
\hline
\end{tabular}

\section{F. HASIL KEGIATAN}

Pada kegiatan PkM ini, dibahas mengenai tentang usaha yang dapat dilakukan untuk tetap sehat dan bugar di saat Idul Fitri dan pandemic Covid-
19. Upaya untuk tetap menjadi sehat dan bugar dilatarbelakangi peningkatan prevalensi obesitas sentral pada usia $\geq 15$ tahun dari $18,8 \%$ pada tahun 2007 , menjadi $31,0 \%$ pada tahun 2018. 
Diperkirakan total kerugian ekonomi akibat obesitas di Indonesia adalah sebesar 78,478 miliar rupiah/ tahun (Wulansari et. al, 2016).

Dalam mempertahankan IMT, selain dilakukan dengan menjaga konsumsi makanan juga dapat dilakukan dengan melakukan aktivitas fisik dan olahraga. Aktivitas fisik merupakan setiap gerakan tubuh yang diakibatkan kerja otot rangka dan meningkatkan pengeluaran tenaga serta energi. Secara umum aktivitas fisik dibagi menjadi 3 kategori berdasarkan intensitas dan besaran kalori yang digunakan yaitu : aktivitas fisik ringan, aktivitas fisik sedang dan aktivitas fisik berat. Aktivitas ini mencakup aktivitas yang dilakukan di sekolah, di tempat kerja, aktivitas dalam keluarga/ rumah tangga, aktivitas selama dalam perjalanan dan aktivitas lain yang dilakukan untuk mengisi waktu senggang sehari-hari.

Puasa Ramadhan memberikan beberapa manfaat antara lain sebagai ibadah, kegiatan untuk menjaha kesehatan tubuh melalui control emosional, memperbaiki profil lipid dan menjaga kondisi tubuh. Apabila seseorang menginginkan penurunan berat badan, maka sebaiknya melaksanakan rumus pengurangan asupan energi dan peningkatan aktifitas fisik. Komponen penting Physical Fitness yaitu endurance, speed, strength, balance, agility, coordination, dan flexibility.

Dalam rangka mendapatkan kesehatan yang optimal, pemateri menyarankan untuk melakukan 3 jenis Latihan yang dapat dilakukan oleh masyarakat yaitu aerobic training, strength training dan lifestyle exercise. Aerobic training adalah jenis olahraga yang merangsang denyut jantung dan laju pernapasan agar meningkat dengan cepat selama sesi olahraga. Aktivitas latihan ini memerlukan oksigen sebagai proses pembuatan energi. Strength training adalah suatu jenis latihan tubuh yang bertujuan untuk meningkatkan kekuatan fisik. lifestyle exercise hanya melibatkan pemilihan untuk menangani aktivitas sehari-hari sedemikian rupa sehingga menjadi kesempatan olahraga ringan. Masyarakat dapat menerapkan formulasi FITT (Frequency, Intensity, Time, Type) sebagai berikut:

1) Frequency. Latihan dilakukan 3-5 kali dalam seminggu.

2) Intensity. Latihan dapat dilakukan dalam 4 jenis, yaitu tinggi, sedang dan rendah. Hal ini perlu dilakukan perhitungan denyut nadi maksimal = $60 \%$ \& 70\% x (220 - Usia).

3) Time. Waktu saat berolahraga sebaiknya 30-60 menit

4) Type: aerobik, penguatan, fleksibilitas.

Selain itu, berdasarkan sesi tanya jawab terdapat beberapa tambahan informasi. Pertanyaan pertama adalah tentang bagaimana cara anak kos dapat menjaga kebugaran Pemateri kedua memberikan jawaban bahwa untuk dapat menjaga kebugaran bisa dengan melakukan aktifitas fisik sehari-hari seperti membersihkan rumah juga melakukan olahraga seperti mengangkat galon atau berjalan kaki ke kampus dari kos-kosan. Pertanyaan kedua yaitu tentang pola makan yang baik jika seseorang ingin menurunkan Berat Badan secara efektif. Pertanyaan ini dijawab oleh pemateri pertama. Penurunan Berat badan sangat dipengaruhi oleh jumlah kalori yang masuk dan keluar. Selain memperhatikan jenis-jenis makanan juga harus diimbangi dengan penambahan porsi latihan olahraga.

Berdasarkan kegiatan webinar dapat ditarik kesimpulan bahwa cara agar tetap sehat dan bugar adalah melalui pola hidup sehat. Pola hidup sehat ini dimulai dari diri sendiri melalui konsumsi makanan yang sehat 
dan beraktifitas fisik atau olahraga minimal 150 menit/ minggu.

\section{G. DAFTAR PUSTAKA}

Al-Hourani, H.M. and M.F. Atoum. 2007. Body composition, nutrient intake and physical activity patterns in young women during Ramadan. Singapore Med J, 2007. 48(10): p. 906-910.

Balitbangkes. 2010. Riset Kesehatan Dasar (RISKESDAS). Kementerian Kesehatan RI: Badan Penelitian dan Pengembangan Kesehatan.

Balitbangkes. 2017. Laporan Hasil Riset Kesehatan Dasar (RISKESDAS) 2017. Kementerian Kesehatan RI: Badan Penelitian dan Pengembangan Kesehatan.

Gharbi, M., M. Akrout, and B. Zouari. 2003. Food intake during and outside Ramadan.East Mediterr Health J, 2003. 9(1-2): p. 131-140.

Ilona L, Setiawan, Nugraha, Nurhayati. Perbedaan Asupan Makanan Pada Akhir Puasa Ramadhan Dengan Satu Minggu, Dua Minggu Dan Tiga Minggu Setelah Idul Fitri Pada Kompi VI Tank Bandung. Jurnal Ilmu Faal Olahraga, Vol.1, No.1.

Wulansari A, Martianto D, Baliwati YF. 2016. Estimasi Kerugian Ekonomi Akibat Obesitas Pada Orang Dewasa di Indonesia. Jurnal Gizi dan Pangan.

\section{H. DOKUMENTASI}
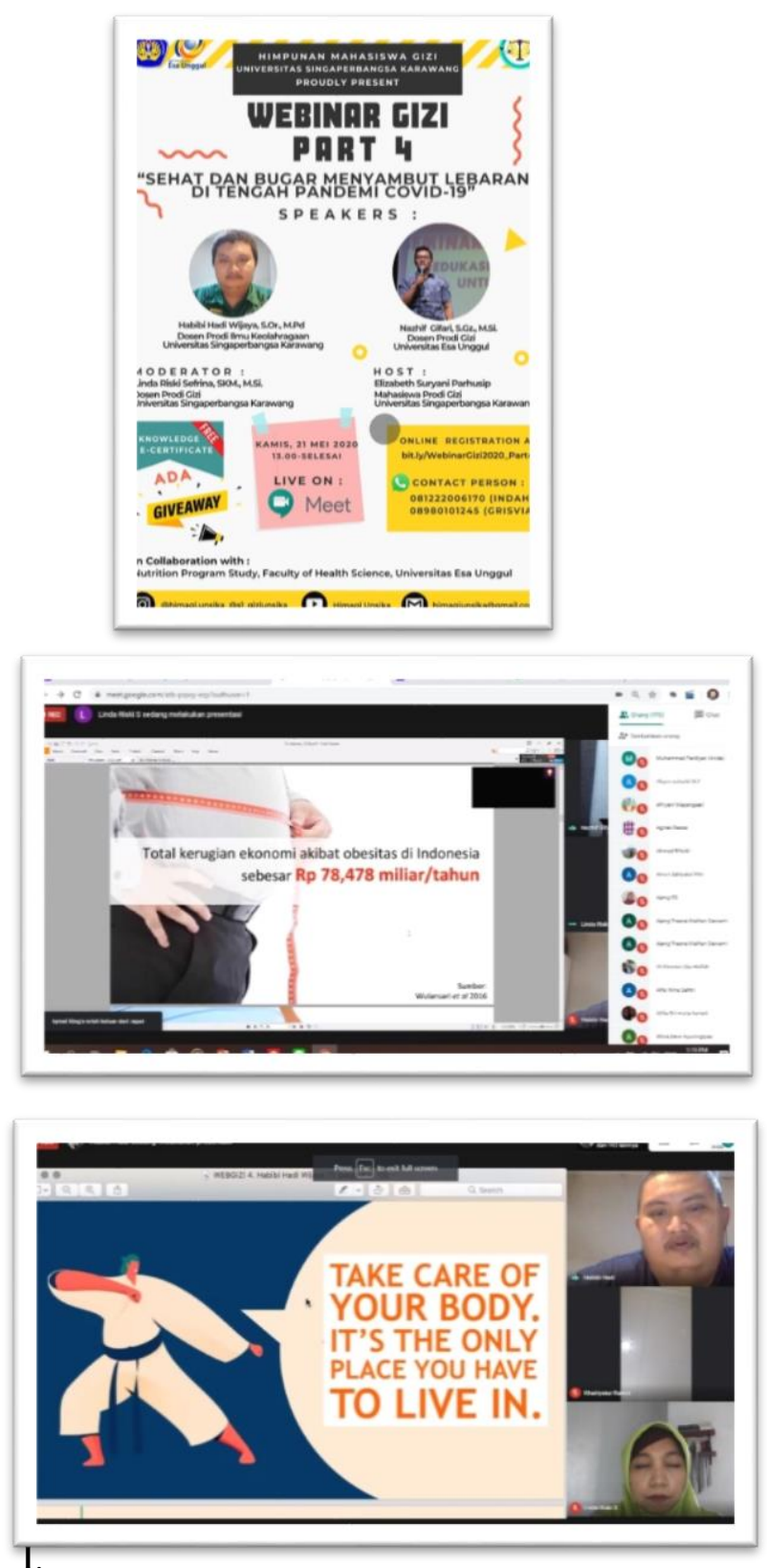